\title{
Bridge Structure from Bamboo Reinforced Concrete Frame
}

\author{
Muhtar, Sri MurniDewi, Wisnumurti, and As'ad Munawir
}

\begin{abstract}
The use of bamboo to replace the steel reinforcement starts from the fact that bamboo has high tensile strength as high as steel. As a renewable material bamboo has much benefit for green construction material. Bridge frame structure is one of structure that can use the bamboo reinforced concrete. The research aims to find out (1) the strength of the bamboo reinforced concrete bridge frame, (2) knowing the behavior of failure characteristic of bamboo reinforced concrete frame, (3) know the strain stress relation on bamboo reinforced concrete element (4) the load deflection relation on bamboo reinforced concrete bridge. Bamboo reinforced concrete bridge frame has span $3000 \mathrm{~mm}$, and $2200 \mathrm{~mm}$ wide made from precast frame bamboo concrete composite. The testing consists of laboratory tests and field tests. In the laboratory tests, the frame was loaded until collapse, and on field test the bridge was loaded with full vehicle load. The results of laboratory tests show an appropriate result between theoretical calculations and experimental testing. Fields tests results show that the bridge was capable of carrying full vehicle loads. The bridge was made with precast system for truss and transverse beam, and cast in place system for vehicle floor.
\end{abstract}

Index Terms - bamboo composite, precast frame, bridge.

\section{INTRODUCTION}

$I^{2}$ n a concept of sustainable structure, the use of bamboo reinforced concrete is much concern at this time [1] [2] [3] [4]. The tensile strength of the bamboo reached $200-300 \mathrm{MPa}$ near to the strength of mild steel. In order to use as a substitute for steel reinforcement, bamboo blades need to be processed first. This process is done to provide water proof properties and increase the surface roughness. Some research on this coating process has been done by Javadian [2016] by use some epoxy resin and smeared with sand particle [5]. Muhtar [2017] and Dewi [2016,2018] adding a peg along the reinforcement to add a sliding contact between the concrete and the bamboo[6] [7]. The design of reinforced concrete bamboo frame truss has been done by Dewi [2011] [8]. The truss nature dominated by the axial force fits perfectly with the bamboo having a high axial strength. Previous use of this framework is for roof trusses and pedestrian bridges... The

A.M. Dewi is with the Department of Civil Engineering, Brawijaya University, Malang, Indonesia (e-mail: srimurnid@ub.ac.id)

Muhtar is with the Department of Civil Engineering, Muhamadiyah University, Jember, Indonesia.

Wisnumurti is with the Department of Civil Engineering, Brawijaya University, Malang, Indonesia

A.Munawir is with the Department of Civil Engineering, Brawijaya

University, Malang, Indonesia. strength of the truss depends on the strength of each axial bars and the strength of the joint connection. The strength of compression bars depends on the bamboo reinforcement strength and concrete compression strength. The strength of tension bars only depends on the strength of bamboo reinforcement. In the previous test, the first crack occurs on the concrete part of tensile bars, continue to the joint connections of the truss. The compression bars relatively never broken. The problem contained in this truss is the strength of the joint connections.

\section{Material AND Testing}

This study deals with the use of concrete bamboo frames (CBF) for highway bridges. The Research consists of laboratory test and field test. Laboratory testing is done until maximum capacity, while testing in the field using a vehicle with full load and half load. The bridge location was in Batu, near Malang City in East Java.

The research used bamboo Petung (Dendrocalamus Asper) aged between 3-5 years, dried in free air approximately 30 days. Bamboo tension test conducted to determine the tensile strength and the elasticity modulus of bamboo. The specimen for the test was $15 \mathrm{~mm}$ thick and width at a length of $300 \mathrm{~mm}$. The test performed in Universal Testing Machine (UTM). From those test obtained an elastic modulus value of 70000 $\mathrm{MPa}$ and tensile strength of $93 \mathrm{MPa}$.

Water proof layers and sand coating aim to make the surface of bamboo reinforcement rougher. The waterproof layers used were Sikadur-752 gel. Some hose-clamps installed in reinforcement bars near the connection to increase the strength of the connection.

\section{A. Bamboo Frames}

The main truss CBF was made with length of $3200 \mathrm{~mm}$ and $1150 \mathrm{~mm}$ height trapezoid shaped as shown in Fig. 1. The effective span was $3000 \mathrm{~mm}$. The cross section of the lower bars were $120 \mathrm{~mm} \times 200 \mathrm{~mm}$, the cross section of upper and diagonal bars was $120 \mathrm{~mm} \times 120 \mathrm{~mm}$, and the cross section of vertical bars were $120 \mathrm{~mm} \times 100 \mathrm{~mm}$. Bamboo stick used for the reinforcement of CBF bars were $15 \mathrm{~mm} \times 15 \mathrm{~mm}$ that has been given a waterproof layer. The lower bars truss has 8 reinforcements, and the other bars have 4 reinforcements. 

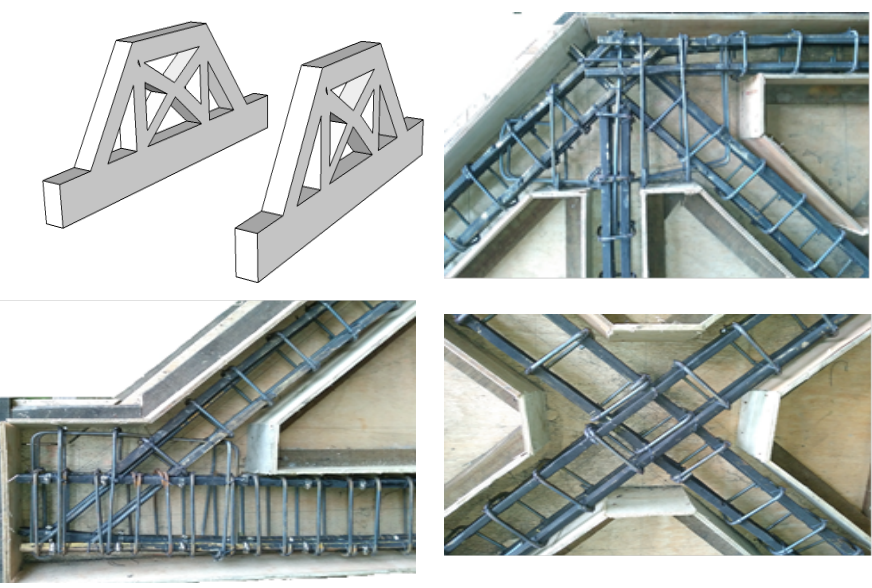

Fig-1: Concrete Bamboo Frame

\section{B. Theoretical Strength}

The theoretical strength of CBF analyzed by linear finite element methods, the triangular mesh elements shown in Fig.2
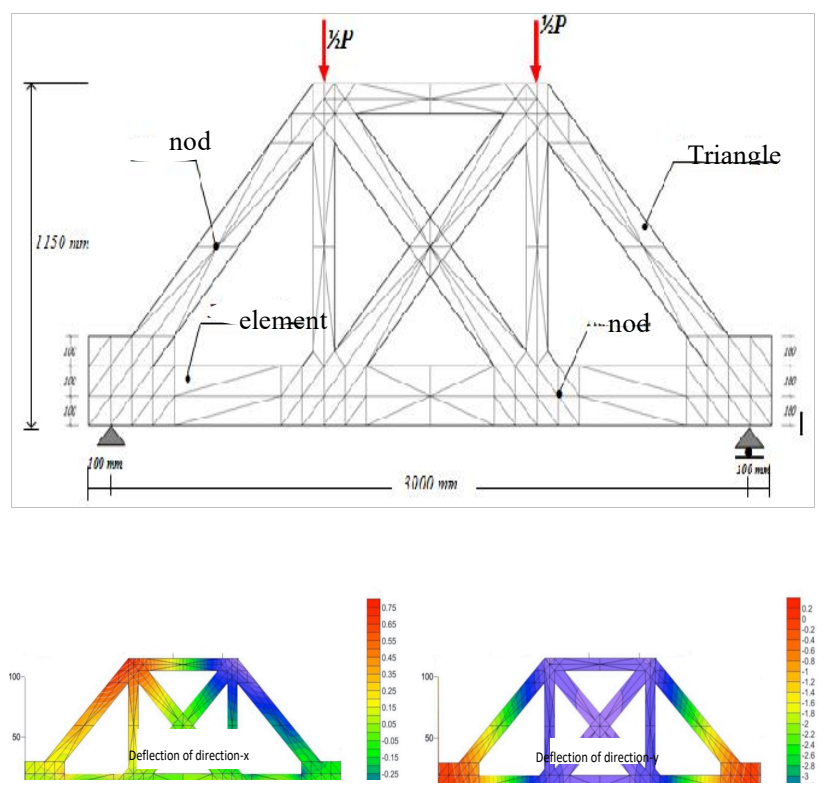

Fig-2: Triangular Finite Element Mesh and Deflection Output for 450 $\mathrm{kN}$ load

\section{Laboratory Test}

The laboratory test of CBF arranged with four point loads as shown in Fig.3. The load applied through the hydraulic jack and read through the load cell. The LVDT were placed in the middle of the span to read the frame deflection.

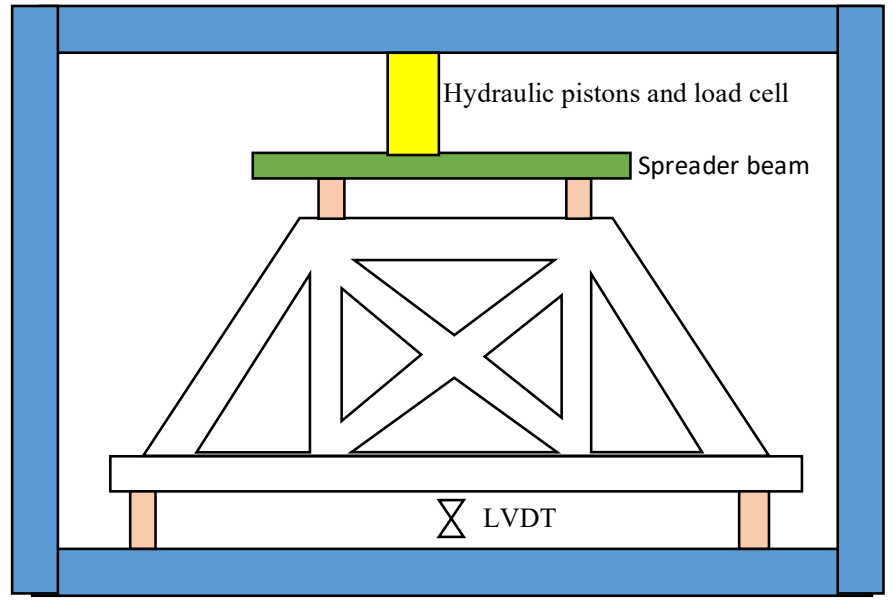

Fif-3: Set Up of Frame Testing in Laboratory

Through the frame loading, it was observed that the first crack was occurs at $80 \mathrm{kN}$. The frame loading stopped at 98 $\mathrm{kN}$ and $7,8 \mathrm{~mm}$ deflection because of the frame capacity is only $110 \mathrm{kN}$. The Load deflection curve and the pattern of cracks shown in Fig.4

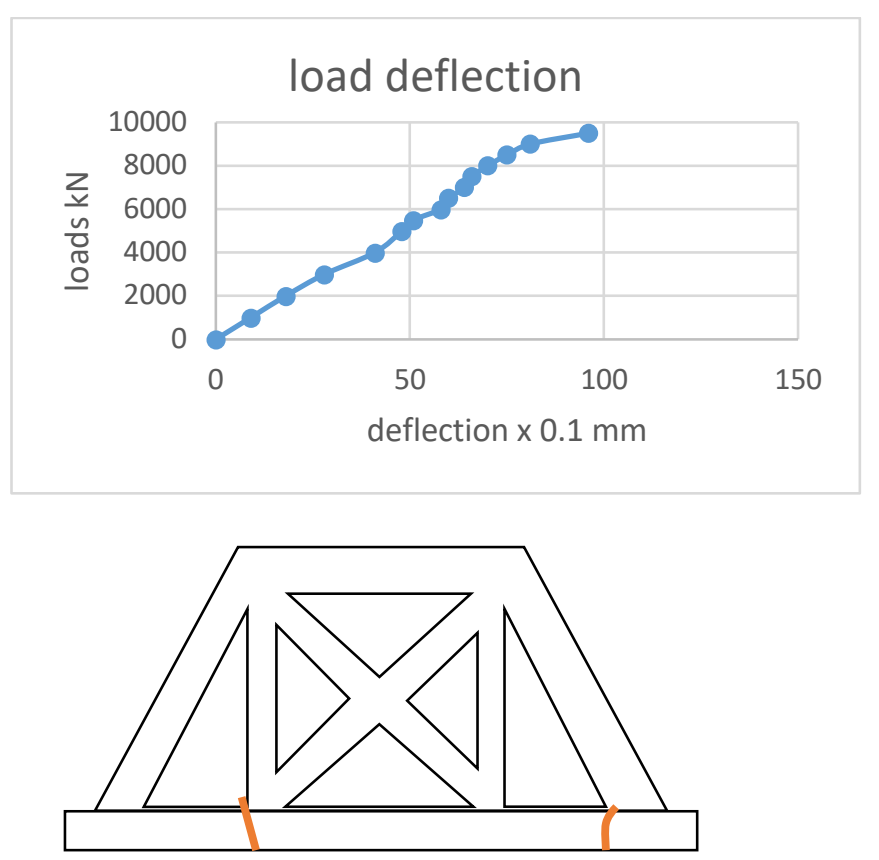

Fig-4: The Load deflection and Frame Failure Crack on Laboratory Test

D. Field Test of Bamboo Reinforced Concrete Bridge

On loading in the field, the bridge was made using two precast $\mathrm{CBF}$ and four precast transverse beams as shown in Fig.5. 


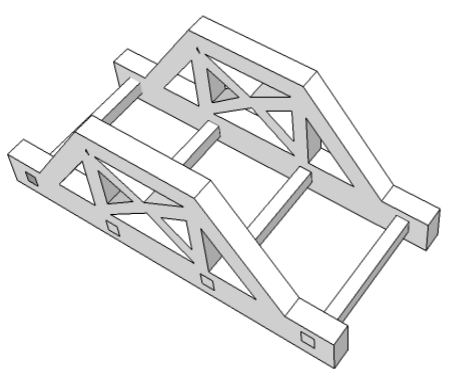

Fig-5: Arrangement of Precast Bridge

The connection of the precast beam to the vertical frame bar is shown in Fig.6. The bolt connection was reinforced with Sika Anchoorfit@.

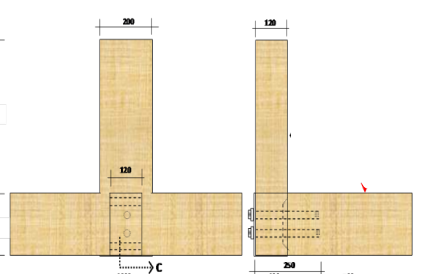

Fig-6: The Beam to Frame Connection

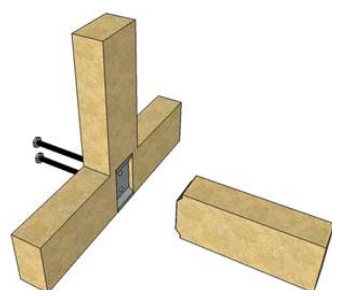

Bridge floor was cast in site with bamboo reinforced concrete. The bamboo reinforcement has sections $15 \mathrm{~mm} \times 15$ $\mathrm{mm}$ arranged at a distance of $100 \mathrm{~mm}$. Spandex $3 \mathrm{~mm}$ thick were used for formwork of the floor. The position of vehicle with full passenger is shown in Fig.7.

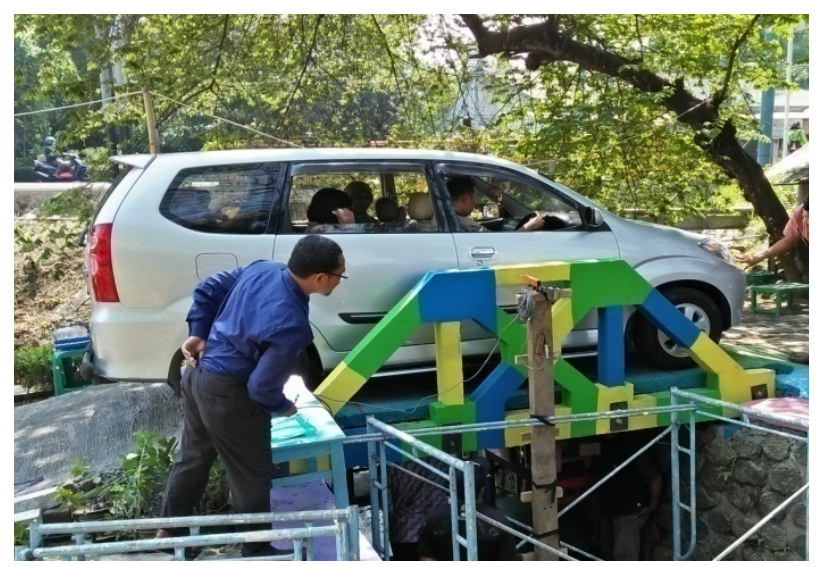

Fig-7: Vehicle Loading

Deflection of each transverse beam was occurred by LVDT in a center of each beam span and record for every position of front wheel of the vehicle. The deflection of the $2^{\text {nd }}$ and $3^{\text {st }}$ transversal beam presented in Fig. 8

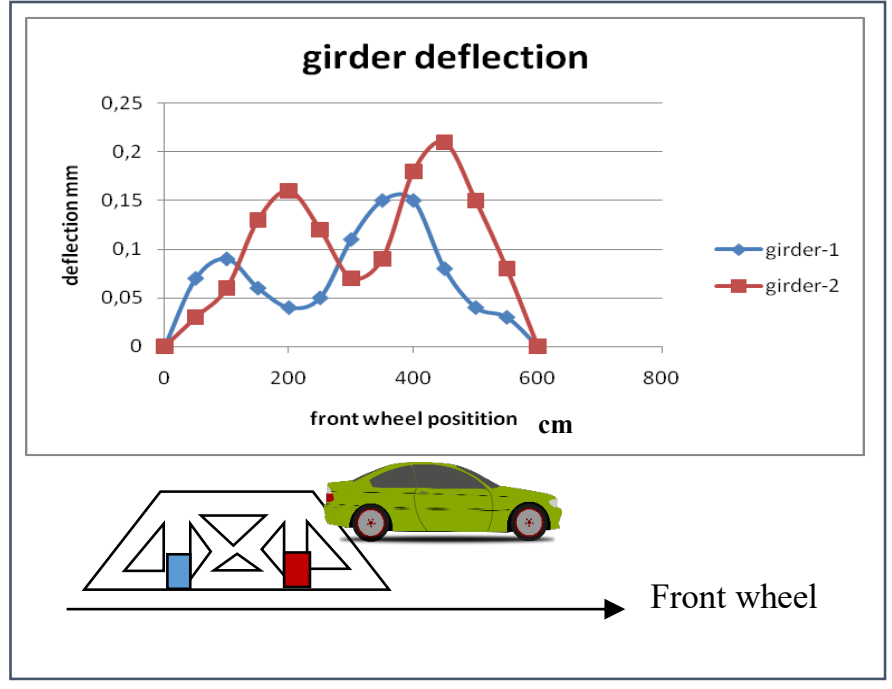

Fig-8: Beam Deflection

The deflection of frame was occurring in a center of each frame, the maximum deflection of frame bridge was $0.14 \mathrm{~mm}$. Comparison between average girders deflection and average frame deflection shown in Fig 9.

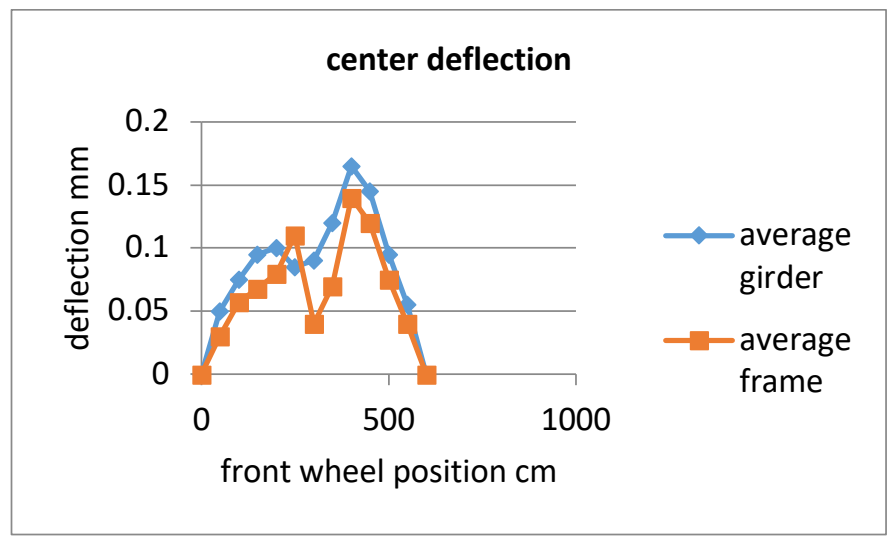

Fig-9: Center Deflection of Girder and Frame

\section{CONCLUSIONS}

This study has presented the laboratory test and field test of bamboo reinforced concrete truss bridge. By compared the results of laboratory tests and field tests, it was seen that the deflections of the bridge were small enough and it were comfortable to the user. The deflection fluctuations occur because the length of the car is equal to the length of the bridge. The maximum deflection occurs when the rear wheel in position of girder and front wheel in the outside of the bridge. Then it was shown that the rear wheel load is heavier than the front wheel load. The problem encountered in precast systems for larger spans is the weight of the precast frame. So it is advisable to span the larger frame used in the site casting system. 


\section{REFERENCES}

[1] Ghavani. "Bamboo as Reinforcement in Structural Concrete Elements, Cement and Concrete Composite," Science Direct, Elsevier,27, 637-649,2005.

[2] S.M.Dewi, "Perilaku Pelat Lapis Komposit Bambu Spesi pada Beban In-plane dan Beban Lentur," Disertasi S3 ITS, Surabaya, 2005.

[3] S.M.Dewi, and T.Wonlele, "Roof Frame from Bamboo Concrete Composite," Journal of Material Science and Engineering-B, vol.1 no 1, 2011.

[4] M.Terai and K.Minami, "Fracture Behavior and Mechanical Properties of Bamboo Reinforced Concrete Members," Fukuyama University, 985 Aza-Sazno Higashimura-cho, Fukuyama 729-0292, Japan Procedia Engineering 10 2967-2972, 2011.

[5] A.Javadian, M.Wielopozki, I.F.Smith, and D.E.Hebel, "Bond-Behavior Study of Newly Developed Bamboo-Composite Reinforcement in Concrete," Construction and Building Materials 122 110-117, 2016.

[6] Muhtar, and S.M. Dewi, "Bond Slip Improvement of Bamboo Reinforcement in Concrete Beam Using Hose Clamp," Proceeding The $2^{\text {nd }}$ International Multidisciplinary Conference, Indonesia, 2016.

[7] S.M.Dewi, and D.Nuralina, "The Recent Research of Bamboo Reinforced Concrete," In MATEC Web of Conferences, Vol. 103, p. 02001). EDP Sciences., 2017.

[8] S.M.Dewi, D.Nuralinah, A.Munawir, and M.N.Wijaya, "Crack Behavior Study of Beam Reinforced Concrete Beam With additional Pegs in Reinforcing," International Journal of Civil Engineering and Technology, Volume 9, Issue 7, pp 1632-1640, July, 2018. 